\title{
Biotic Control of Calcium Cycling in Northern Hardwood Forests: Acid Rain and Aging Forests
}

\author{
Steven P. Hamburg, ${ }^{1 *}$ Ruth D. Yanai, ${ }^{2}$ Mary A. Arthur, ${ }^{3}$ Joel D. Blum, ${ }^{4}$ \\ and Thomas G. Siccama ${ }^{5}$
}

\begin{abstract}
${ }^{1}$ Center for Environmental Studies, Brown University, Box 1943, Providence, Rhode Island 02912, USA; ${ }^{2}$ School of Environmental Science and Forestry, State University of New York, Syracuse, New York 13210, USA; ${ }^{3}$ Department of Forestry, University of Kentucky, Lexington, Kentucky 40546, USA; ${ }^{4}$ Department of Geological Sciences, University of Michigan, Ann Arbor, Michigan 48109, USA; ${ }^{5}$ School of Forestry and Environmental Studies, Yale University, New Haven, Connecticutt 06511, USA
\end{abstract}

\begin{abstract}
Observations of declining base saturation in soils and declining calcium (Ca) in streamwater have contributed to concerns that prolonged exposure to acid rain threatens forest health and productivity. We suggest that these changes could be caused, in part, by aging of the forests. To test this possibility, we characterized Ca cycling in previously harvested, variously aged northern hardwood stands over 15-18 years. The Ca content and concentrations in the forest floor and the density of snails, which require Ca for growth, increased in young stands (less than 30 years old) and decreased in older stands (more than 30 years old) over the measurement period. Similarly, the concentrations of $\mathrm{Ca}$ in litterfall decreased with stand age, and hydrologic export of $\mathrm{Ca}$ from a young stand was higher than that from an old stand. Ecosystem bud-
\end{abstract}

\section{INTRODUCTION}

Prolonged exposure to acid rain, along with a decline in the calcium $(\mathrm{Ca})$ in precipitation (Hedin and others 1994), is thought to have decreased the availability of base cations in forest soils (Hallbacken and Tamm 1986; Robarge and Johnson 1992; Johnson and others 1994; Lawrence and others 1999; Huntington 2000; Driscoll and others

Received 19 April 2002; accepted 6 December 2002; published online May 20, 2003.

*Corresponding author; e-mail: Steven_Hamburg@Brown.edu gets suggest that the supply of $\mathrm{Ca}$ from the mineral soil to other parts of the ecosystem is large (3.3-4.7 g Ca $\mathrm{m}^{-2} \mathrm{y}^{-1}$ ) in young forest stands but negligible or negative in older stands $\left(-1 \mathrm{~g} \mathrm{Ca} \mathrm{m} \mathrm{m}^{-2} \mathrm{y}^{-1}\right)$. This difference in Ca mobilization between young and old stands is large compared to the changes in soil Ca that can reasonably be attributed to acid precipitation (less than $1 \mathrm{~g} \mathrm{~m}^{-2} \mathrm{y}^{-1}$ ). We conclude that changes in soil and streamwater $\mathrm{Ca}$ in maturing forests do not necessarily indicate an important loss of bioavailable $\mathrm{Ca}$. Trace amounts of apatite in the mineral soil may be the source of Ca needed for forest regrowth.

Key words: calcium; forest succession; acid rain; snails; litterfall; forest floor; northern hardwoods.
2001). These losses could threaten forest ecosystems, since pools of available Ca seem insufficient to ensure long-term forest health (Graveland and others 1994; NAPAP 1998; Johnson and others 2000; Driscoll and others 2001; Hames and others 2002).

In addition to external factors that induce changes in biogeochemical cycling, such as the atmospheric deposition of strong acids, there are also internal factors associated with species composition, forest growth, and stand age (Alban 1982; Finzi and others 1998; Dijkstra and Smits 2002). In central New Hampshire, when northern hardwood forests regenerate after clear-cutting, dominance shifts 
from species with high tissue Ca concentrations, such as pin cherry, to species with lower tissue $\mathrm{Ca}$, such as beech, (Fahey and others 1998; Likens and Bormann 1970), a shift that may affect the cycling of Ca. With forest succession and growth come changes in root length and depth distribution (Dijkstra and Smits 2002), mycorrhizal associations, Ca uptake capacity, and the production of low-molecular-weight organic acids (Finzi and others 1998), all of which may play a role in changing $\mathrm{Ca}$ cycling as forests age.

It can be difficult to distinguish the effects of environmental stress, such as acid rain, from other changes in forested ecosystems (Arthur and Yanai 2000). The hardwood forests of the northeastern United States are primarily second-growth forests, largely originating from post-Civil War abandonment of agricultural land and logging in the late 1880 s and early 1900s (Whitney 1994). Because large areas of the landscape are vegetated by forests of a similar age, they could exhibit synchronous changes in biogeochemical cycling associated with forest succession, and these changes could be confused with responses to environmental stresses, such as air pollution.

To help distinguish the effects of stand age and species composition from the effects of acid deposition, we examined several indicators of Ca cycling in northern hardwood stands of different ages in the White Mountains of New Hampshire. These indicators were snail abundance and Ca content, Ca in litterfall and the forest floor, and Ca export in streamwater from small first-order watersheds. Snails are highly sensitive bioindicators of $\mathrm{Ca}$ availability (Hotopp 2002), because they require a large amount of Ca to grow and reproduce compared to most biota (Wareborn 1992; Gardenfors 1992). Calcium dynamics in the forest floor reflect changes in inputs in leaf litter, fine roots, and throughfall, as well as changes in biological uptake with forest succession. Our use of repeated measurements of stands of different ages ensures that any patterns attributed to stand age are not due to other differences among sites, such as soil parent material or harvesting practices (Arthur and Yanai 2000; Yanai and others 2000). We also quantified the amount of Ca mobilized by young and old forests, and examined $\mathrm{Ca}$ in soil extracts to determine possible sources of the Ca obtained by young forests.

\section{Methods}

Snails

Snails and slugs were collected in 1980 (Strayer and others 1986) and again in 1996-98 in seven stands that ranged in age from 2 to 80 years after clearcutting. All of the sites were in the White Mountain region within $70 \mathrm{~km}$ of the Hubbard Brook Experimental Forest (HBEF) $\left(43^{\circ} 56^{\prime} \mathrm{N}, 71^{\circ} 45^{\prime} \mathrm{W}\right)$ on soils derived from unsorted basal tills and similar crystalline parent materials. Changes in snail Ca were derived from repeated measures at the same sites, so differences between sites due to cutting treatments or site quality are controlled for. None of the sites had been burned or fertilized as part of the management regimes employed.

At each site, $360.56-\mathrm{m}^{2}$ cardboard sheets (one small site received only 20) were placed in a systematic grid on top of the forest floor in early June. Twice during each summer within 2-3 days of a 7-mm or greater rain event, all of the snails and slugs on the underside of the cardboard were collected. The snails were preserved in alcohol and identified, and a subsample of the 1996-98 snails was dried and weighed. The Ca content of five snails collected in the 1990s from each of the four most important taxa (weight basis) from both young and old stands was determined using microwave digestion $\left(210^{\circ} \mathrm{C}\right.$ in $15.7-\mathrm{M}$ nitric acid) and inductively coupled plasma-atomic emission spectroscopy (ICP-AES).

The populations of snails in young and old stands were tested for differences in weight and Ca concentration. There were no significant differences between young and old stands $(P>0.10, t$-test $)$, except for Discus cronkhitei. For this species, the average snail mass for each site was calculated from the best-fit linear regression of snail mass versus stand age; snails from the oldest forests weighed nearly twice as much as the snails from the youngest sites $\left(R^{2}=0.36\right.$; $\left.P<0.05\right)$. All other taxa were described using average weights and Ca concentrations.

\section{Forest Floor}

Forest floor (O horizon and A horizon, where present) block samples $(10 \times 10 \mathrm{~cm})$ were collected in 1979-80 (Federer 1984) and again in 1994-95 (Yanai and others 1999, 2000) in 13 forest stands ranging in age from 1 to 120 years after clearcutting. Six of the sites were at the Bartlett Experimental Forest, one was at the HBEF, and six others were scattered around the White Mountain National Forest. The sites used for forest floor sampling had histories similar to those used for the snail sampling described above. Ten blocks were collected and composited on each of five transects at each of the sites. Forest floor samples were air-dried and sieved, and a subsample was ashed and dissolved in 6-M nitric acid; the concentration of $\mathrm{Ca}$ 
was determined using ICP-AES. Data from forest floor horizons were combined for this analysis.

\section{Litterfall}

Calcium in litterfall was measured for 3 years (1993-95) in the same 13 stands used to study forest floor dynamics. In each stand, 15 litterfall baskets, each with a collecting area of $0.146 \mathrm{~m}^{2}$, were deployed on the five sampling lines. The three samples from each sampling line were pooled, sorted by species, dried $\left(60^{\circ} \mathrm{C}\right)$, and weighed. The chemistry of the litterfall was determined using freshly fallen leaves collected during rainless periods. Fresh leaves were dried, weighed, ground, ashed, and dissolved in 6-M nitric acid, and the concentration of Ca was determined using ICPAES.

\section{Soil Extractions}

We used sequential extractions to define Ca pools in samples collected using the quantitative pit method (Hamburg 1984) in 1983 in a mature northern hardwood forest (with spruce-fir forest at the uppermost elevations) that was cut in the 1880s and again in the 1910s (HBEF watershed 5). The soils were collected by depth (O horizon, $0-10 \mathrm{~cm}$, $10-20 \mathrm{~cm}$, and $20 \mathrm{~cm}$ to the $\mathrm{C}$ horizon) using $0.5-\mathrm{m}^{2}$ pits distributed across the watershed (Huntington and others 1988). In 2001, air-dried soils from five soil pits were extracted in sequence from a 0.5 -g soil sample; the solid residue was then separated from the solution by centrifugation after each of the following steps: (a) First, the soil was exchanged overnight with $5 \mathrm{ml}$ of $1-\mathrm{M} \mathrm{NH}_{4} \mathrm{Cl}(\mathrm{pH}$ $=7$ ) to remove the exchangeable cations. (b) The residue was next leached overnight in $5 \mathrm{ml}$ of $1-\mathrm{M}$ $\mathrm{HNO}_{3}$ to remove nonsilicate minerals such as apatite and calcite. Our studies have shown that this treatment dissolves more than $75 \%$ of the apatite and calcite in Hubbard Brook soils, yet it dissolves less than $0.3 \%$ of the silicate fraction (Blum and others 2002). (c) Finally, the residue was microwave-digested in $10 \mathrm{ml}$ of a mixture of concentrated $\mathrm{HF}, \mathrm{HNO}_{3}$, and $\mathrm{HCl}$ at high pressure and $210^{\circ} \mathrm{C}$ to dissolve silicate minerals. Major and trace elements in all of the solutions were measured using ICP-AES with both internal and external calibration.

Streamwater Streamwater comparisons come from two first-order watersheds at HBEF: watershed 5 (WS-5) (whole-tree harvested in 1983-84) and watershed 6 (WS-6) (biogeochemical reference) (Likens and others 1998). Both watersheds were northern hardwood forests (with spruce-fir forests at the uppermost elevations) that were cut in the 1880s and again in the 1910s; in addition, there was some salvage logging after the 1938 hurricane. Both watersheds were monitored continuously for flow and weekly for water chemistry.

\section{Ca Budgets}

A budget of Ca cycling rates was constructed using repeated measurements at multiple sites. This approach protected our comparisons from a chance association between stand age and species composition, site characteristics, or a history of exposure to acid rain. The net Ca flux from mineral soil was calculated as the sum of changes in Ca storage in the forest floor and vegetation, inputs of $\mathrm{Ca}$ in precipitation and slash from logging, and outputs of $\mathrm{Ca}$ in streamwater. Calcium accumulation in vegetation of young stands was based on measurements from the late 1960s (Marks and Bormann 1972) and 1988-94 (Fahey and others 1998). Calcium accumulation in old stands was based on measurements of growth during the periods 1964-69 and 1987-92 at HBEF (Likens and others 1998). The nutrient concentrations in the living aboveground biomass were verified using destructive sampling in an adjacent watershed with a similar disturbance history (Arthur and others 2001). Precipitation and streamwater were measured from 1980 to 1992 and 1984 to 1995, respectively, at HBEF (Likens and others 1998). Accumulation of $\mathrm{Ca}$ in the forests floor was measured from 1979-80 to 1994-95 (Yanai and others 1999); stands were classified as more than or less than 30 years old at the time of the second measurement. Slash decomposition following harvesting was estimated to take 30 years and to involve $40 \%-60 \%$ of the Ca in aboveground and belowground living biomass of an old forest. This estimate is conservative in that more intensive harvests would require even greater rates of $\mathrm{Ca}$ supply from soil sources. Changes in snail $\mathrm{Ca}$, although statistically significant $(P<0.02)$, were not included in the budgets because they were numerically insignificant (less than $10 \mathrm{mg} \mathrm{m}^{-2}$ ) compared to other fluxes.

\section{Statistics}

Comparisons in changes over time in forest floor $\mathrm{Ca}$ content and concentrations and snail numbers and Ca contents for sites $<30$ years old and those $>30$ years old were done using $t$-tests. Linear regression was used to predict litterfall Ca content as a function of stand age. Linear regression was also used to predict the annual Ca export from WS-5 based on the annual export of Ca from WS-6 prior to har- 
vesting (1966-83). With the aid of this model, the predicted annual Ca export from WS-5 for the period 1984-95 was compared with the actual annual Ca export using a paired $t$-test.

\section{Results AND Discussion}

If acid rain were the dominant factor causing changes in Ca cycling, we would expect $\mathrm{Ca}$ availability to be declining across the landscape. Instead, we found that changes in snails, forest floors, and leaf litter depended on the age of the stands we studied. Snails were three times more numerous in stands less than 30 years old than in stands more than 30 years old $(18 \pm 3.5$ [SE] versus $6 \pm 1.4$ snails $/ \mathrm{m}^{2}$ cardboard for young and old stands, respectively; $t=3.5$; $d f=26 ; P=0.002$ ), and they contained about twice as much Ca $(68+12$ [SE] versus $23 \pm 5 \mathrm{mg} \mathrm{Ca} / \mathrm{m}^{2}$ cardboard for young and old stands, respectively; $t=3.7 ; d f=26 ; P=0.001$ ). Over the 18-year sampling period, changes in snail Ca were significantly different in young and old forests $\left(12 \pm 10[\mathrm{SE}]\right.$ versus $-10 \pm 5 \mathrm{mg} \mathrm{Ca} / \mathrm{m}^{2}$ cardboard $/ 18$ years; $t=3.8 ; d f=4 ; P=0.02$ ), with all three stands less than 30 years old increasing and three stands more than 30 years old declining, and one remaining low throughout (Figure 1A).

In the forest floor, the highest Ca concentrations were observed in stands less than 30 years old; the lowest were in a stand that was more than 100 years old (Figure 1B). Over the 15-year sampling period, changes in Ca concentrations in the forest floor were significantly different in young and old forests $(P=0.04)$; they increased in four of the five youngest stands, whereas the eight older stands all had Ca concentrations that were lower in 1994-95 than in 1979-80. Changes in total Ca mass in the forest floor showed a similar pattern; all five of the youngest stands increased, and six of the eight older stands decreased $(P=0.03)$ (Yanai and others 1999).

The changes in Ca cycling that occur as the forest ages are also reflected in the $\mathrm{Ca}$ concentration of litterfall over a period of 120 years $\left(P=0.04, R^{2}=\right.$ 0.34) (Figure 1C). Some of the variation in litterfall Ca concentrations is due to differences in species composition. For examples Ca-rich pin cherry (Prunus pensylvanica L.), striped maple (Acer pensylvanicum L.), white ash (Fraxinus americana L.), and yellow (Betula lutea Michx. F.) and white birch (Betula papyrifera Marsh.) were all common in young stands $(70 \%$ of basal area). Older stands had much less of these high-concentration species $(50 \%$ of basal area). Older stands had more beech (Fagus grandifolia Ehrh.) and red maple (Acer rubrum L.)
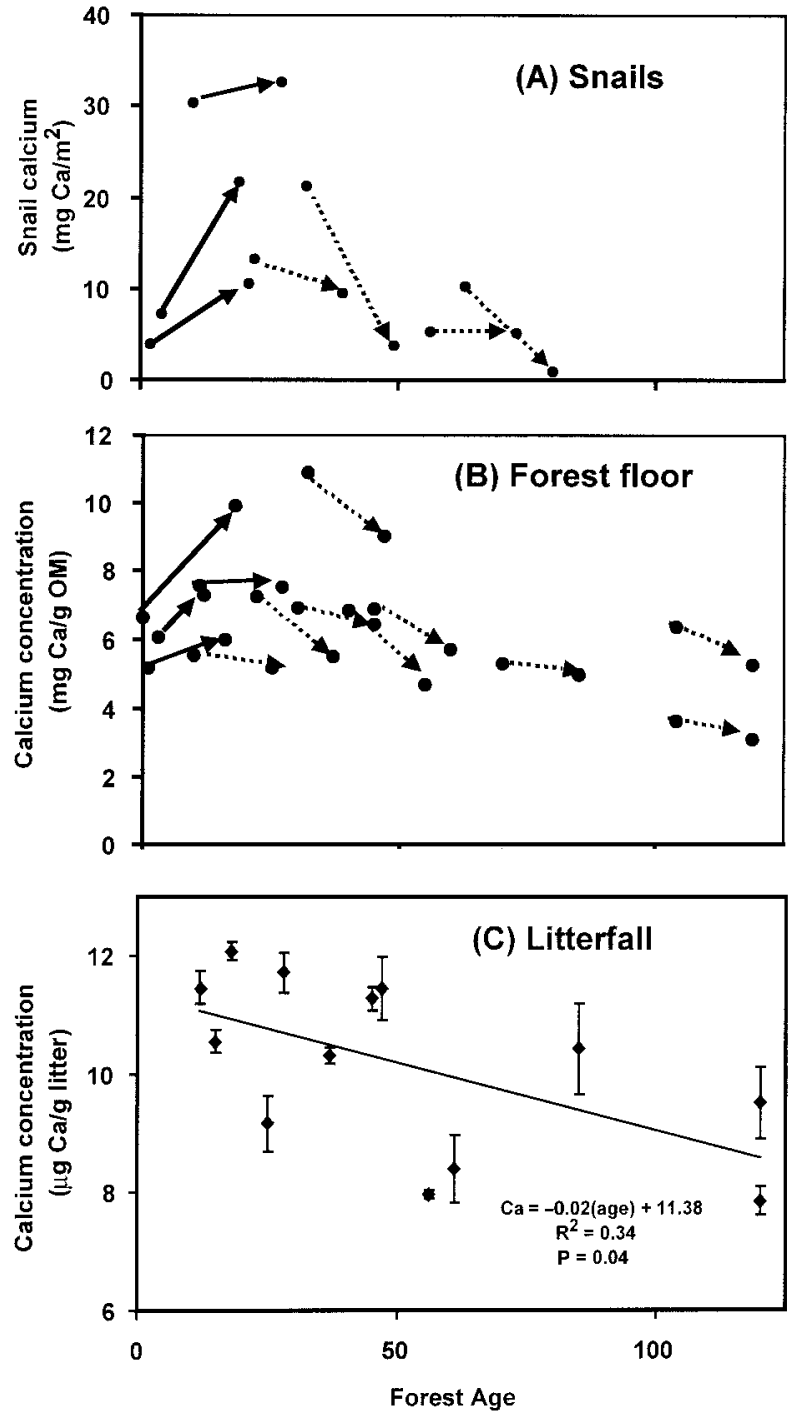

Figure 1. (A) Changes in calcium (Ca) content of snails in seven northern hardwood stands across the White Mountains, New Hampshire, measured in 1980 and again at the same sites in 1996-98. Arrows connect the data from a single stand at two points in time; solid lines represent increases in snail $\mathrm{Ca}$, and dashed lines represent declines. (B) Changes in concentrations of $\mathrm{Ca}$ in the forest floor of 13 northern hardwood stands across the White Mountains measured in 1979 or 1980 and again in 1994 or 1995. OM, organic matter. Arrows connect the data from a single stand at two points in time; solid lines represent increases in forest floor Ca concentrations, and dashed lines represent declines. (C) Concentrations of $\mathrm{Ca}$ in litter fall from the same 13 stands sampled for forest floor changes.

(40\% of basal area, as compared to $5 \%$ in young stands); these species are lower in Ca. Further research is needed to determine whether the differences between the young and the old stands are 
(A)

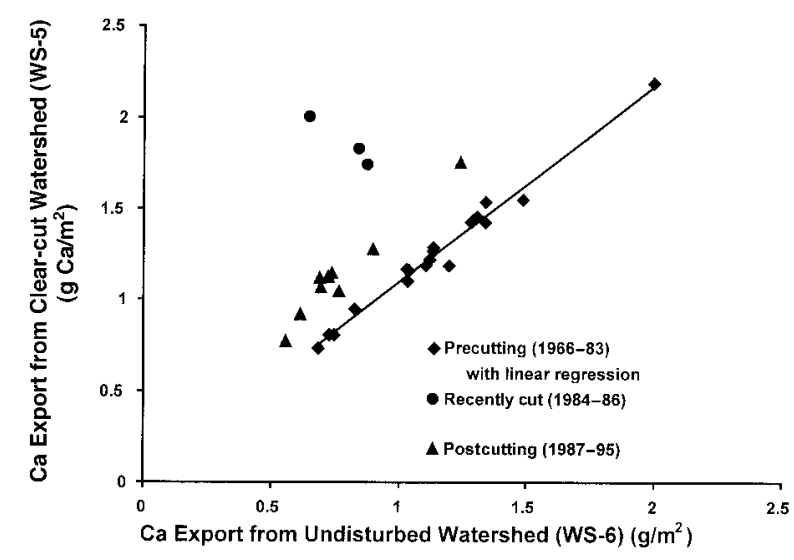

(B)

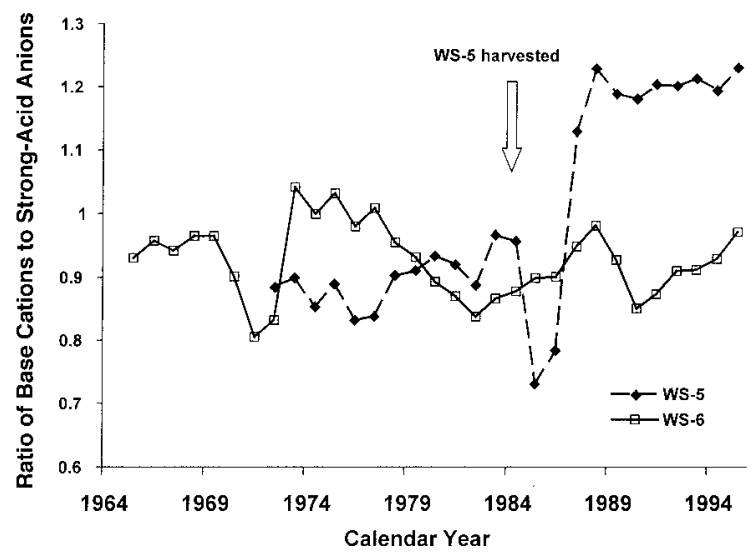

Figure 2. (A) Comparison of streamwater exports of calcium (Ca) from a whole-tree harvested (WS-5) to an undisturbed (WS-6) first-order watershed in the Hubbard Brook Experimental Forest from 1964 to 1995. (B) Ratio of base cations to strong anions (sulfate and nitrate) in streamwater from WS-6 and WS-5 from 1964 to 1995 are plotted on a calendar-year basis.

due primarily to changes in species composition or to other factors related to forest disturbance.

Heightened Ca mobility in soils after forest harvesting is also reflected in an increase in the annual streamwater export of $\mathrm{Ca}(P=0.003)$ (Figure $2 \mathrm{~A})$. The net export of $\mathrm{Ca}$ in streamwater increases immediately after forest harvest (Likens and others 1998) (Figure 2A) and remains elevated for at least 15 years. Similarly, the ratio of base cations to strong acid anions in streamwater was higher in the recently cut stand (Figure 2B). This is an unexpected finding, because other investigators have reported that the export of base cations is controlled largely by the export of strong acid anions (Likens and others 1996), and it has been assumed that uptake by regrowing vegetation would increase $\mathrm{Ca}$ retention as it does nitrogen (Martin and others 1984).

We therefore conclude that young forests or early-successional species are able to readily mobilize Ca from the mineral soil, building a nutrient pool in the forest floor as well as in living biomass. The continued elevation of streamwater export of $\mathrm{Ca}$ suggests that these young stands mobilize more $\mathrm{Ca}$ than they are able to accumulate in biomass, which may result in increased concentrations of exchangeable $\mathrm{Ca}$ in the deeper soil horizons, as observed by Johnson and others (1997). This enhanced Ca cycling continues for about 3 decades after the disturbance, much longer than the 2 or 3 years of cation release attributable to nitrification (Martin and others 1984). This pattern is most likely characteristic of the young soils that developed on the glacial tills of the northeastern United States, which have larger stores of $\mathrm{Ca}$ in weatherable minerals than the older soils of the southeastern United States (Huntington 2000).

The increase in $\mathrm{Ca}$ in the vegetation and forest floor of younger forest stands reflects a net transfer of Ca from mineral soil to these ecosystem compartments. We can quantify the net Ca flux from mineral soil in young and old forest stands by summing the changes in Ca storage in the forest floor and vegetation, the inputs of $\mathrm{Ca}$ in precipitation and slash from logging, and the outputs of $\mathrm{Ca}$ in streamwater (Figure 3). The forest floor is a Ca sink in young stands but a Ca source in older stands, and the vegetation is a stronger sink in young stands than in older stands. Precipitation inputs of $\mathrm{Ca}$ are independent of stand age, whereas the streamwater export of $\mathrm{Ca}$ is consistently higher from stands less than 30 years old (Likens and others 1998). To balance the Ca budget of young stands, the mineral soil must be a large net source of Ca to other ecosystem compartments (Figure 3).

To assess the amount of easily weatherable $\mathrm{Ca}$ that may be available to regrowing northern hardwood forests, we measured soil Ca pools using sequential extractions and digestions. The salt-exchangeable fraction $\left(\mathrm{NH}_{4} \mathrm{Cl}\right)$ has commonly been equated with the plant-available pool, whereas the nonexchangeable pool is assumed to be dominated by silicate minerals. The salt extraction removed small amounts of $\mathrm{Ca}$, magnesium $(\mathrm{Mg})$, sodium $(\mathrm{Na})$, and potassium $(\mathrm{K})$, as expected. However, when this treatment was followed by an acid extraction (1-M $\left.\mathrm{HNO}_{3}\right)$, a relatively large pool of Ca was removed $\left(65 \mathrm{~g} \mathrm{Ca} / \mathrm{m}^{2}\right.$ in the $\mathrm{E}$ and $\mathrm{B}$ horizons and $60 \mathrm{~g} \mathrm{Ca} / \mathrm{m}^{2}$ per $10 \mathrm{~cm}$ of depth in the C horizon). However, the amount of $\mathrm{Na}$, phosphorus (P), and $\mathrm{K}$ in the extract was not proportional to their 
A

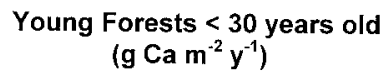

$\left(\mathrm{g} \mathrm{Ca} \mathrm{m}^{-2} \mathrm{y}^{-1}\right)$

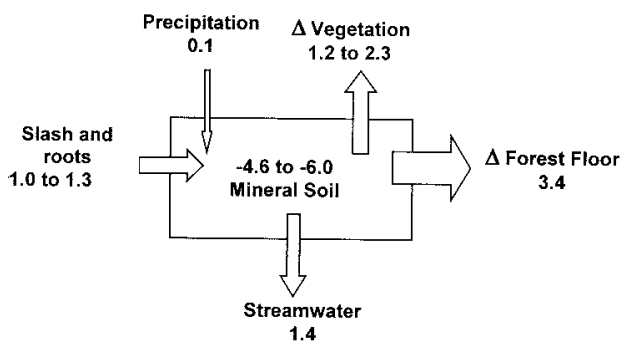

B Older Forests $>30$ years old $\left(\mathrm{g} \mathrm{Ca} \mathrm{m}^{-2} \mathrm{y}^{-1}\right)$

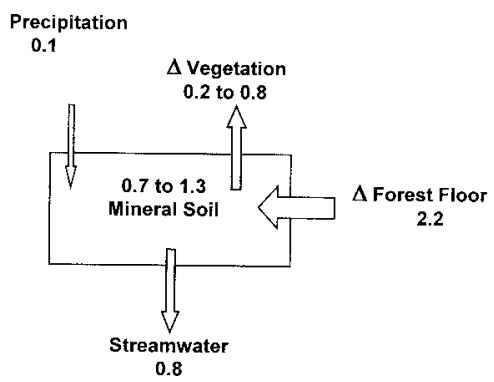

Figure 3. Net annual flux of calcium (Ca) into and out of the mineral soil in (A) young (less than 30 years old) and (B) old (more than 30 years old) northern hardwood forest stands after clear-cutting $\left(\mathrm{g} \mathrm{m}^{-2} \mathrm{y}^{-1}\right)$ abundance in any of the silicate minerals that are important sources of $\mathrm{Ca}$ in the region.

The cation ratios (Figure 4) suggest that this treatment dissolved nonsilicate minerals, such as calcite and apatite, which are more rapidly weathered than silicate minerals, and are ubiquitous as small inclusions in the silicate minerals of the soil parent material, as observed via cathodoluminescence imaging of soil thin sections (Jacobson and Blum 2000; Blum and others 2002). Roots and associated mycorrhizae, by acidifying the rhizosphere, may access the same mineral reservoir as the acid extraction (Rogers and others 1998; Van Breemen and others 2000; Wallander 2000). Digestions of the soil after the acid-leaching released large amounts of base cations, in ratios consistent with the dissolution of silicate minerals (Figure 4). These pools become available to plants only very slowly.

We think that the source of Ca to young stands may be this pool of nonsilicate minerals. There is some evidence that trees with ectomycorrhizal associations are best able to access this pool (Blum and others 2002), but ectomycorrhizal species are not the ones that dominate the regrowth of the northern hardwood forest in central New Hampshire. Alternatively, young trees may be better able than older ones to mobilize Ca from silicate minerals or from organically bound pools. Calcium oxalate has been proposed as another overlooked source of available Ca (Bailey and others 2003), but our evidence does not support this idea. Acid-extractable Ca concentrations are greatest at depth, which suggests that unweathered minerals are the source, rather than leaf or fungal calcium oxalate. More research is needed to clarify the source and mechanisms of this greater Ca supply in young stands, with attention to rooting characteristics, transpiration rates (Ryan and Yoder 1997), root exudates, and mycorrhizal associations (Quideau and others 1996). To predict the risk of Ca depletion by repeated forest harvest and acid rain, we will need to determine the size of the pool tapped by young stands.

According to our calculations, the rate of Ca mobilization achieved by young forests $(4.6-6.0 \mathrm{~g} \mathrm{Ca}$ $\left.\mathrm{m}^{-2} \mathrm{y}^{-1}\right)$ is large compared to the rate attributed to acid precipitation at Hubbard Brook in mature forests $\left(0.4 \mathrm{~g} \mathrm{Ca} \mathrm{m}^{-2} \mathrm{y}^{-1}\right)$ (Likens and others 1996). Even if all of the acid delivered in precipitation (Likens and Bormann 1995) were to result in an equivalent $\mathrm{Ca}$ release from the soil, only $1.4 \mathrm{~g} \mathrm{Ca}$ $\mathrm{m}^{-2} \mathrm{y}^{-1}$ would be mobilized. The idea of biotic control of nutrient cycling in forested watersheds is not a new one (Bormann and Likens 1979), but it has not previously been included in models that link acid precipitation and cation depletion. Declining $\mathrm{Ca}$ export in streamwater from the 1960s to the 1990s and the failure of both the amount of Ca export and the ratio of base cations to strong acid anions to recover following implementation of the 1970 Clean Air Act have been attributed to the depletion of Ca from the soil exchange complex by acid precipitation (Likens and others 1996). Acid rain undoubtedly has caused changes in Ca cycling, but the differences between young and old stands are remarkable. Therefore, the changes observed in Ca export and streamwater chemistry over the past 30 years must have been influenced by the aging of the forest over the period of observation, as well as by environmental factors.

The combined effects of forest regrowth and acid precipitation are undoubtedly reducing the soil reservoir of $\mathrm{Ca}$, but the sustained Ca release in young stands suggests that the biologically available reservoir is much larger than previously believed (Driscoll and others 2001). Evidently, young forests are accessing Ca from pools other than those traditionally considered available, such as the nonsilicate pool revealed by the acid extraction. If this is 

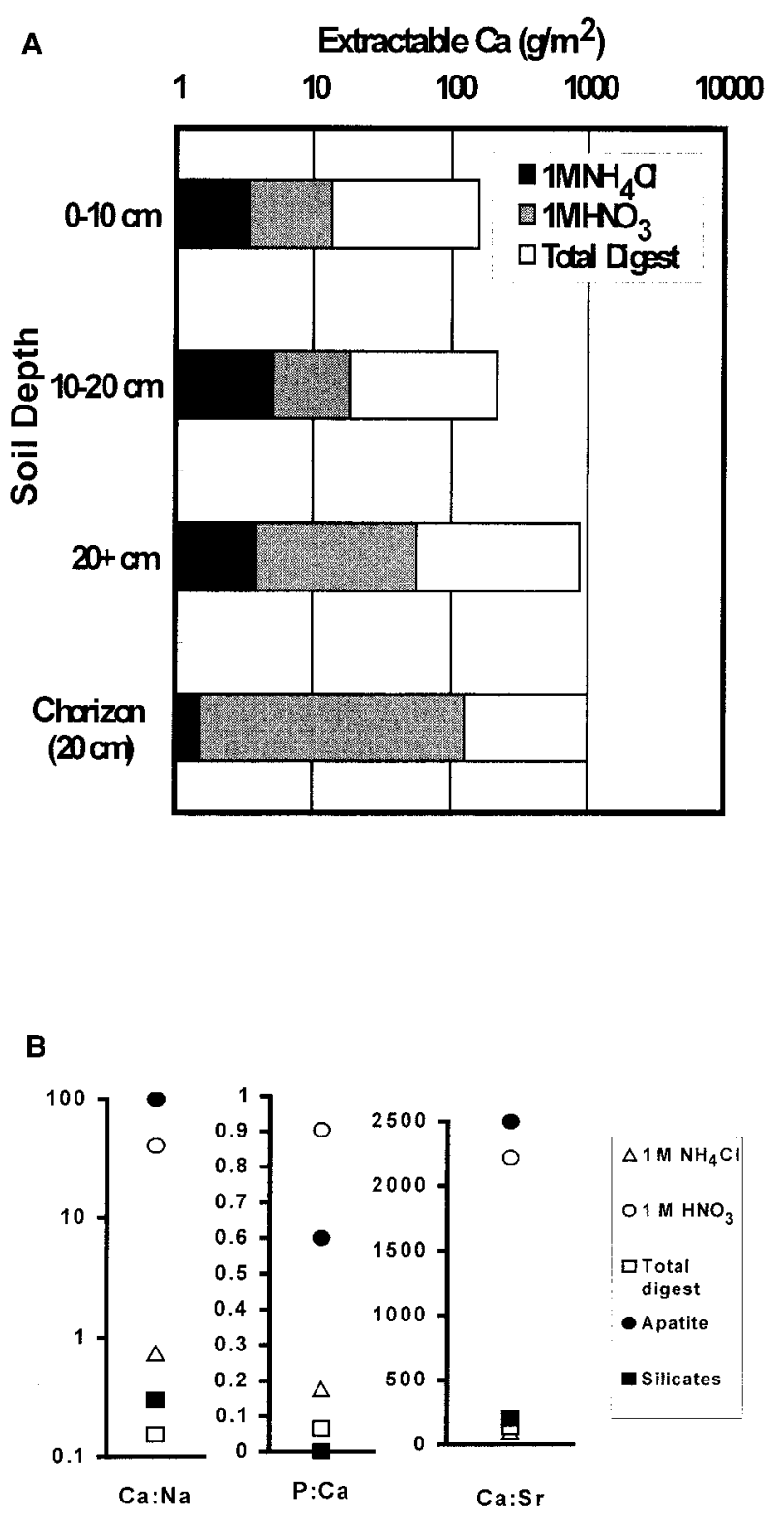

Figure 4. (A) Calcium (Ca) pools in sequential soil extracts from the soils of a mature northern hardwood forest: $\mathrm{NH}_{4} \mathrm{Cl}$-exchangeable pool, a $\mathrm{l}-\mathrm{M} \mathrm{HNO} 3$ extraction, the total digest. Contents of the $\mathrm{C}$ horizon were calculated using a depth of $20 \mathrm{~cm}$. (B) Mean molar ratios of calcium to sodium (Ca:Na), phosphorus to calcium (P:Ca), and calcium to strontium (Ca:Sr) from the $\mathrm{C}$ horizon of the extractants in A.

the case, the potential for acid precipitation to deplete available $\mathrm{Ca}$ is probably greater in old stands than in young ones. A full understanding of the nature of the biotic control of Ca cycling and its effect on the predicted rate of soil depletion by acid precipitation is critical to the effective design of environmental policy.

\section{ACKNOWLEDGMENTS}

The data utilized in this study were collected with funding from the National Science Foundation, the US Department of Agriculture NRICGP, and the Andrew W. Mellon Foundation. We thank J. Aber, D. Binkley, D. Buso, C. Driscoll, C. Eager, and G. Likens for helpful discussions and reviews of earlier versions of this manuscript. C. Neilson, D. Pletscher, and M. Smith were central to the collection and analysis of the snail data. This is a contribution to the Hubbard Brook Ecosystem Study. The Hubbard Brook Experimental Forest is administered by the USDA-FS, Northeast Forest Experiment Station.

\section{REFERENCES}

Alban DH. 1982. Effects of nutrient accumulation by aspen, spruce, and pine on soil properties. Soil Sci Soc Am J 46:85361.

Arthur MA, Hamburg SP, Siccama TG. 2001. The accuracy of allometric estimates of aboveground living biomass and nutrient contents of a northern hardwood forest. Can J For Res 31:11-17.

Arthur MA, Yanai RD. 2000. Distinguishing the effects of environmental stress and forest succession on changes in the forest floor. Kor J Eco 23:83-8.

Bailey SW, Buso DC, Likens GE. Implications of sodium mass balance for interpreting the calcium cycle of a northern hardwood ecosystem. Ecology (in press).

Blum JD, Klaue A, Nezat C, Driscoll CT, Johnson CE, Siccama TG, Eager C, Fahey TJ, Likens GE. 2002. Mycorrhizal weathering of apatite as an important calcium source in a base-poor forest ecosystems. Nature 417:729-31.

Bormann FH, Likens GE. 1979. Pattern and process in a forested ecosystem. New York: Springer-Verlag.

Dijkstra FA, Smits MM. 2002. Tree species effects on calcium cycling: the role of calcium uptake in deep soils. Ecosystems 5:385-98

Driscoll CT, Lawrence GB, Bulger AJ, Butler TJ, Cronan CS, Eager C, Lambert KF, Likens GE, Stoddard JL, Weathers KC. 2001. Acid deposition in the northeastern United States: sources and inputs, ecosystem effects, and management strategies. BioScience 51:180-98.

Fahey TJ, Battles JJ, Wilson GF. 1998. Responses of early successional northern hardwood forests to changes in nutrient availability. Eco Monogr 68:183-212.

Federer CA. 1984. Organic matter and nitrogen content of the forest floor in even-aged northern hardwoods. Can J For Res 14:763-7.

Finzi AC, Canham CD, Van Breemen N. 1998. Canopy tree-soil interactions within temperate forests: species effects on $\mathrm{pH}$ and cations. Ecol Appl 8:447-54.

Gardenfors U. 1992. Effects of artificial liming on land snail populations. J Appl Ecol 29:50-4.

Graveland J, Van der Wal R, Van Balen JH, Van Noordwijk AJ. 1994. Poor reproduction in passerines from decline of snail abundance on acidified soils. Nature 368:446-8.

Hallbacken L, Tamm CO. 1986. Changes in soil acidity from 1927 to 1982-1984 in a forest area of south-west Sweden. Scand J For Res 1:219-32. 
Hamburg SP. 1984. Effects of forest growth on soil nitrogen and organic matter pools following release from subsistence agriculture. In: Stone EL, editor. Forest soils and treatment Impacts. Knoxville (TN): University of Tennessee Press. p 145-58.

Hames RS, Rosenberg KV, Lowe JD, Barker SE, Dhondt RA. 2002. Adverse effects of acid rain on the distribution of the wood thrush Hylocichla mustelina in North America. Proc Natl Acad Sci USA 99:11235-40.

Hedin LO, Granat L, Likens GE, Buishand TA, Galloway JN, Butler TJ, Rodhe H. 1994. Steep declines in atmospheric base cations in regions of Europe and North America. Nature 367: $351-4$.

Hotopp KO. 2002. Land snail and soil calcium in central Appalachian mountain forest. Southeast Nat 1:27-44.

Huntington TG. 2000. The potential for calcium depletion in forest ecosystems of southeastern United States: review and analysis. Global Biogeochem Cycles 14:623-38.

Huntington TG, Ryan DF, Hamburg SP. 1988. Estimating soil nitrogen and carbon pools in a northern hardwood forest ecosystem. Soil Sci Soc Am J 52:1162-7.

Jacobson AD, Blum JD. 2000. Ca/Sr and Sr-87/Sr-86 geochemistry of disseminated calcite in Himalayan silicate rocks from Nanga Parbat: influence on river-water chemistry. Geology 28:463-6.

Johnson AH, Anderson SB, Siccama TG. 1994. Acid rain and the soils of the Adirondacks. I. Changes in $\mathrm{pH}$ and available calcium. Can J For Res 24:193-8.

Johnson CE, Driscoll CT, Siccama TG, Likens GE. 2000. Element fluxes and landscape position in a northern hardwood forest watershed ecosystem. Ecosystems 3:159-84.

Johnson CE, Romanowicz RB, Siccama TG. 1997. Conservation of exchangeable cations after clear-cutting of a northern hardwood forest. Can J For Res 27:859-68.

Lawrence GB, David MB, Lovett GM, Murdoch PS, Burns DA, Stoddard JL, Baldigo BP, Porter JH, Thompson AW. 1999. Soil calcium status and the response of stream chemistry to changing acid deposition rates. Ecol Appl 9: 1059-72.

Likens GE, Bormann FH. 1995. Biogeochemistry of a forested ecosystem 2nd ed. New York: Springer-Verlag. 66 p.

Likens GE, Bormann FH. 1970. Chemical analyses of plant tissue from the Hubbard Brook Ecosystem in New Hampshire. Yale Univ School For Bull 79:1-25.

Likens GE, Driscoll CT, Buso DC. 1996. Long-term effects of acid rain: response and recovery of a forest ecosystem. Science 272:244-6.
Likens GE, Driscoll CT, Buso DC, Siccama TG, Johnson CE, Lovett GM, Fahey TJ, Reiners WA, Ryan DF, Martin CW, and others. 1998. The biogeochemistry of calcium at Hubbard Brook. Biogeochemistry 41:89-173.

Marks PL, Bormann FH. 1972. Revegetation following forest cutting: mechanisms for return to steady-state nutrient cycling. Science 176:914-5.

Martin CW, Noel DS, Federer CA. 1984. Effects of forest clearcutting in New England on stream chemistry. J Environ Qual 13:204-10.

[NAPAP] National Acid Precipitation Assessment Program. 1998. Biennial report to Congress: an integrated assessment. Washington (DC): National Acid Precipitation Assessment Program. $148 \mathrm{p}$.

Quideau SA, Chadwick OA, Graham RC, Wood HB. 1996. Base cation biogeochemistry and weathering under oak and pine: a controlled long-term experiment. Biogeochemistry 35:377-98.

Robarge WP, Johnson DW. 1992. The effects of acidic deposition on forested soils. Adv Agron 47:1-83.

Rogers JR, Bennett PC, Choi WJ. 1998. Feldspars as a source of nutrients for microorganisms. Am Mineral 83:1532-40.

Ryan MG, Yoder BJ. 1997. Hydraulic limits to tree height and tree growth. BioScience 47:235-42.

Strayer D, Pletscher DH, Hamburg SP, Nodvin SC. 1986. The effects of forest disturbance on land gastropod communities in northern New England. Can J Zool 64:2094-8.

Van Breemen N, Finlay R, Lundstrom U, Jongmans AG, Giesler R, Olsson M. 2000. Mycorrhizal weathering: a true case of mineral plant nutrition? Biogeochemistry 49:53-67.

Wallander H. 2000. Uptake of P from apatite by Pinus sylvestris seedlings colonized by different ectomycorrhizal fungi. Plant Soil 218:249-56.

Wareborn I. 1992. Changes in land mollusk fauna and soil chemistry in an inland district in southern Sweden. Ecography $15: 62-9$.

Whitney GG. 1994. From coastal wilderness to fruited plain. New York: Cambridge University Press. 451 p p.

Yanai RD, Arthur MA, Siccama TG, Federer CA. 2000. Challenges of measuring forest floor organic matter dynamics: repeated measures from a chronosequence. For Ecol Manage 138:273-83.

Yanai RD, Siccama TG, Arthur MA, Federer CA, Friedland AJ. 1999. Accumulation and depletion of base cations in forest floors in the northeastern US. Ecology 80:2774-87. 